\title{
Communication
}

\section{Improvement of Toluene Selectivity via the Application of an Ethanol Oxidizing Catalytic Cell Upstream of a YSZ-Based Sensor for Air Monitoring Applications}

\author{
Tomoaki Sato ${ }^{1}$, Michael Breedon ${ }^{2,3}$ and Norio Miura ${ }^{3, *}$
}

1 Interdisciplinary Graduate School of Engineering Sciences, Kyushu University, Kasuga-shi, Fukuoka 816-8580, Japan; E-Mail: mr-t-satoh@mms.kyushu-u.ac.jp

2 Japan Society for the Promotion of Science, Chiyoda-ku, Tokyo 102-8471, Japan; E-Mail: m.breedon@astec.kyushu-u.ac.jp

3 Art, Science and Technology Center for Cooperative Research, Kyushu University, Kasuga-shi, Fukuoka 816-8580, Japan

* Author to whom correspondence should be addressed; E-Mail: miurano@astec.kyushu-u.ac.jp; Tel.: +81-92-583-8852; Fax: +81-92-583-8976.

Received: 29 February 2012; in revised form: 16 March 2012 / Accepted: 20 March 2012 / Published: 11 April 2012

Abstract: The sensing characteristics of a yttria-stabilized zirconia (YSZ)-based sensor utilizing a $\mathrm{NiO}$ sensing-electrode (SE) towards toluene $\left(\mathrm{C}_{7} \mathrm{H}_{8}\right)$ and interfering gases $\left(\mathrm{C}_{3} \mathrm{H}_{6}, \mathrm{H}_{2}, \mathrm{CO}, \mathrm{NO}_{2}\right.$ and $\left.\mathrm{C}_{2} \mathrm{H}_{5} \mathrm{OH}\right)$ were evaluated with a view to selective $\mathrm{C}_{7} \mathrm{H}_{8}$ monitoring in indoor atmospheres. The fabricated YSZ-based sensor showed preferential

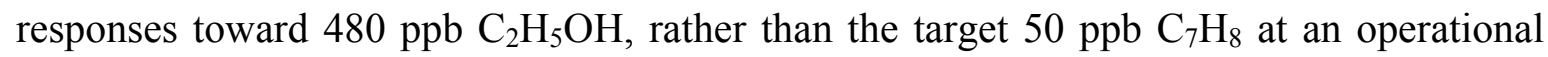
temperature of $450{ }^{\circ} \mathrm{C}$ under humid conditions $(\mathrm{RH} \simeq 32 \%)$. To overcome this limitation, the catalytic activity of $\mathrm{Cr}_{2} \mathrm{O}_{3}, \mathrm{SnO}_{2}, \mathrm{Fe}_{2} \mathrm{O}_{3}$ and $\mathrm{NiO}$ powders were evaluated for their selective ethanol oxidation ability. Among these oxides, $\mathrm{SnO}_{2}$ was found to selectively oxidize $\mathrm{C}_{2} \mathrm{H}_{5} \mathrm{OH}$, thus improving $\mathrm{C}_{7} \mathrm{H}_{8}$ selectivity. An inline pre-catalytic cell loaded with $\mathrm{SnO}_{2}$ powder was installed upstream of the YSZ-based sensor utilizing NiO-SE, which enabled the following excellent abilities by selectively catalyzing common interfering gases; sensitive ppb level detection of $\mathrm{C}_{7} \mathrm{H}_{8}$ lower than the established Japanese Guideline value; low interferences from $50 \mathrm{ppb}_{3} \mathrm{H}_{6}, 500 \mathrm{ppb} \mathrm{H}_{2}, 100 \mathrm{ppb} \mathrm{CO}, 40 \mathrm{ppb} \mathrm{NO}$, as well as $480 \mathrm{ppb}_{2} \mathrm{H}_{5} \mathrm{OH}$. These operational characteristics are all indicative that the developed sensor may be suitable for real-time $\mathrm{C}_{7} \mathrm{H}_{8}$ concentration monitoring in indoor environments. 
Keywords: indoor air monitoring; toluene; YSZ; mixed potential; ethanol; ppb levels

\section{Introduction}

Since the wider awareness of the environmental and health concerns that volatile organic compounds (VOCs) pose, the development of high-performance VOCs sensors has been of great interest [1-6]. This is due to their disruptive nature in atmospheric chemistry as well as their hazardous effects on the human body. For example, the production of photochemical smog [7], and the direct negative effects to our health, which are cumulatively referred to as sick building syndrome, are both exacerbated by the presence of atmospheric VOCs [8]. However, the development of reliable VOCs sensors have been hampered by the extremely low target detection levels, which are often in the order of several parts per billion (ppb) [9,10]. Additionally, negative effects on sensing performance can be caused by many interfering gases, such as $\mathrm{HCs}$, NOx and $\mathrm{H}_{2} \mathrm{O}$, etc. in the sensing environment, which often exist at significantly higher ppm concentrations [11-13].

Recently, we reported that a mixed-potential type gas sensor, which consists of yttria-stabilized zirconia (YSZ) and a NiO sensing-electrode (SE), gave sensitive responses towards toluene, a typical and often representative VOC which exists in indoor atmospheres at ppb levels [14,15]. In addition, low negative interferences of $\mathrm{C}_{3} \mathrm{H}_{6}, \mathrm{H}_{2}, \mathrm{CO}$ and $\mathrm{NO}_{2}$ were observed, suggesting a high possibility for a selective VOC sensor. This sensor may be useful for real world VOC monitoring and indoor sensing applications, such as VOC detection in conjunction with heating, ventilation, and air conditioning (HVAC) control systems for the prevention of sick building syndrome. The sensing performance of the developed sensor must also be capable of selectively discriminating against unique indoor gases when monitoring VOC levels. Ethanol $\left(\mathrm{C}_{2} \mathrm{H}_{5} \mathrm{OH}\right)$ is perhaps the most common interfering gas in indoor environments because the concentration of ethanol temporarily spikes owing to its culinary use, alcoholic beverage consumption, disinfectant use, and due to its adoption as a general solvent in some cleaning products [16]. In this paper, the sensing characteristics towards toluene and high concentrations of ethanol were evaluated for a NiO/YSZ-based sensor, aiming at the selective detection of ppb levels of toluene for indoor sensing applications.

\section{Experimental}

A tubular YSZ (8 mol\% $\mathrm{Y}_{2} \mathrm{O}_{3}$ doped $\mathrm{ZrO}_{2}$, Nikkato, Japan); $10 \mathrm{~mm}$ in length and $3 \mathrm{~mm}$ in diameter, was used as both the solid-electrolyte and mechanical support of the sensor. NiO powder (99.9\%, Kishida Chemical, Japan) was thoroughly mixed with $\alpha$-terpineol; and the resulting NiO paste, as well as a commercial Pt paste (TR-7601, Tanaka Kikinzoku, Japan) were respectively painted on the outer and inner surfaces of the YSZ tube. The painted YSZ tube was dried at $130{ }^{\circ} \mathrm{C}$, and then calcined in air at $1,000{ }^{\circ} \mathrm{C}$ for $2 \mathrm{~h}$, to form the NiO-SE and Pt-RE. Pt wires were wound on the electrodes, acting as current collectors.

The gas sensing evaluation system is presented in Figure 1. The system consisted of gas cylinders (NIST certified) equipped with mass flow controllers to accurately mix sample gas concentrations; a water vapor generator to humidify sample gas; and a digital electrometer which measures the potential 
difference between $\mathrm{SE}$ and RE as a sensing signal. A quartz cell loaded with $20 \mathrm{mg}$ catalyst powder was applied upstream of the VOC sensor. The gas responses of the fabricated sensor were measured at an operational temperature of $450{ }^{\circ} \mathrm{C}$, under the following conditions: 21 vol\% $\mathrm{O}_{2}, 1.35 \mathrm{vol} \% \mathrm{H}_{2} \mathrm{O}$ $(\mathrm{RH} \simeq 32 \%)$ and $400 \mathrm{ppm} \mathrm{CO}_{2}$, in order to replicate a realistic atmospheric environment. The total gas flow rate was fixed at $100 \mathrm{~cm}^{3} \cdot \mathrm{min}^{-1}$. The selected sample gases were $50 \mathrm{ppb}$ toluene $\left(\mathrm{C}_{7} \mathrm{H}_{8}\right)$ as a representative VOC gas, $50 \mathrm{ppb}_{3} \mathrm{H}_{6}, 500 \mathrm{ppb} \mathrm{H}_{2}, 100 \mathrm{ppb} \mathrm{CO}, 40 \mathrm{ppb} \mathrm{NO}$, and 80-480 ppb ethanol as interfering gases, considering the Japanese guideline value for toluene (70 ppb) [17]; and average or higher concentrations for interfering gases [11-13], to evaluate the sensor in challenging circumstances.

Figure 1. Schematic view of the gas sensor evaluation system.

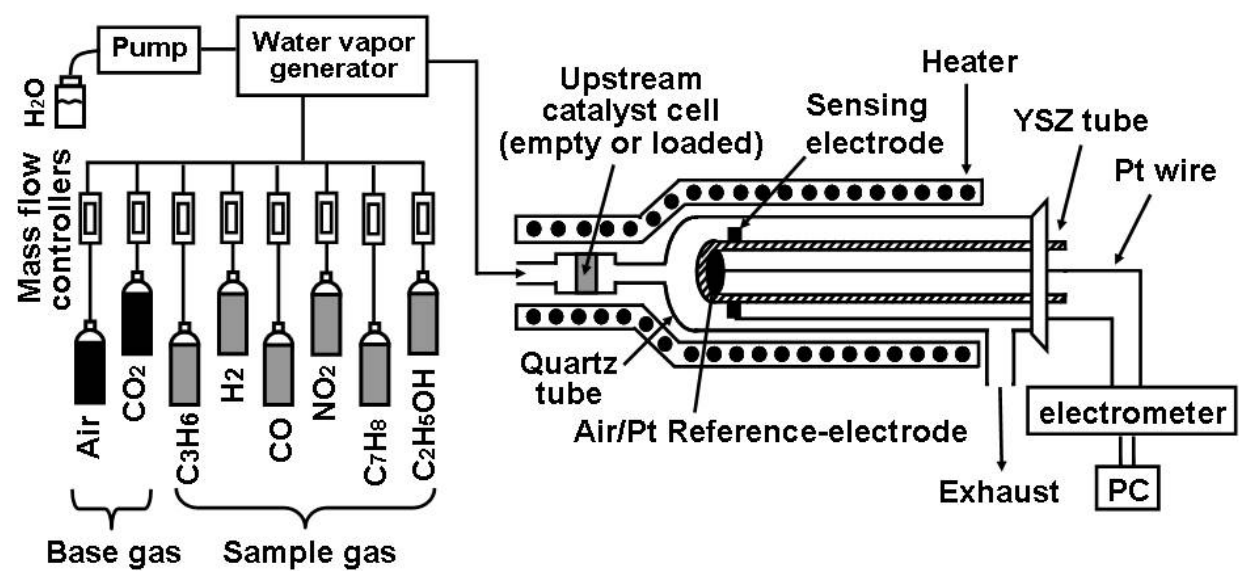

The gas-phase catalytic activity of $\mathrm{Cr}_{2} \mathrm{O}_{3}, \mathrm{SnO}_{2}, \mathrm{Fe}_{2} \mathrm{O}_{3}$ and $\mathrm{NiO}$ powders was evaluated under the same conditions as the constructed sensor. Each commercial oxide powder (Kojundo Chemical Lab. and Kishida Chemical, Japan) was sintered at $1,000{ }^{\circ} \mathrm{C}$ for $2 \mathrm{~h}$, and $20 \mathrm{mg}$ of each powder was separately loaded into a quartz catalytic cell maintained at $450{ }^{\circ} \mathrm{C}$. The downstream gas concentrations of $50 \mathrm{ppb}$ toluene and $80 \mathrm{ppb}$ ethanol after passing through the catalytic cell was measured by a YSZ-based sensor utilizing a $\mathrm{NiO}\left(+20 \mathrm{wt} \%\right.$ nano $\left.\mathrm{Al}_{2} \mathrm{O}_{3}\right)-\mathrm{SE}$, which was fabricated, as per our group's basic procedure for gas sensor fabrication $[14,15]$.

\section{Results and Discussion}

As seen in our previous paper [15], a YSZ-based sensor utilizing NiO-SE gave high responses towards several kinds of VOCs, such as toluene, $m$-xylene, benzene, ethylbenzene, styrene, and formaldehyde; with low negative effects caused by $\mathrm{C}_{3} \mathrm{H}_{6}, \mathrm{H}_{2}, \mathrm{CO}$ and $\mathrm{NO}_{2}$. For the purpose of indoor sensor applications, the evaluation of sensing characteristics towards common indoor gases is of great interest. Figure 2 shows the response transients of the sensor using NiO-SE towards ppb levels of toluene and ethanol, with the later being one of the most significant interfering gases in indoor atmospheres, due to its higher average concentrations [16]. Unfortunately, the fabricated sensor exhibited preferential responses towards ethanol, rather than to the desired toluene. This behavior is similar to other potentiometric YSZ-based sensors reported elsewhere [1], indicating that NiO-SE has an extremely high catalytic activity toward the electrochemical reaction of ethanol rather than toluene, at the triple phase boundary (TPB). The electromotive force (emf) drift after 9 min exposure to either 
toluene or ethanol was less than $-1 \mathrm{mV} / \mathrm{min}$, indicating that for practical purposes the sensor had almost reached a steady state emf.

Figure 2. Response transients of YSZ-based sensor utilizing NiO-SE towards toluene and ethanol at an operational temperature of $450{ }^{\circ} \mathrm{C}$ under humid conditions $(\mathrm{RH} \simeq 32 \%)$.

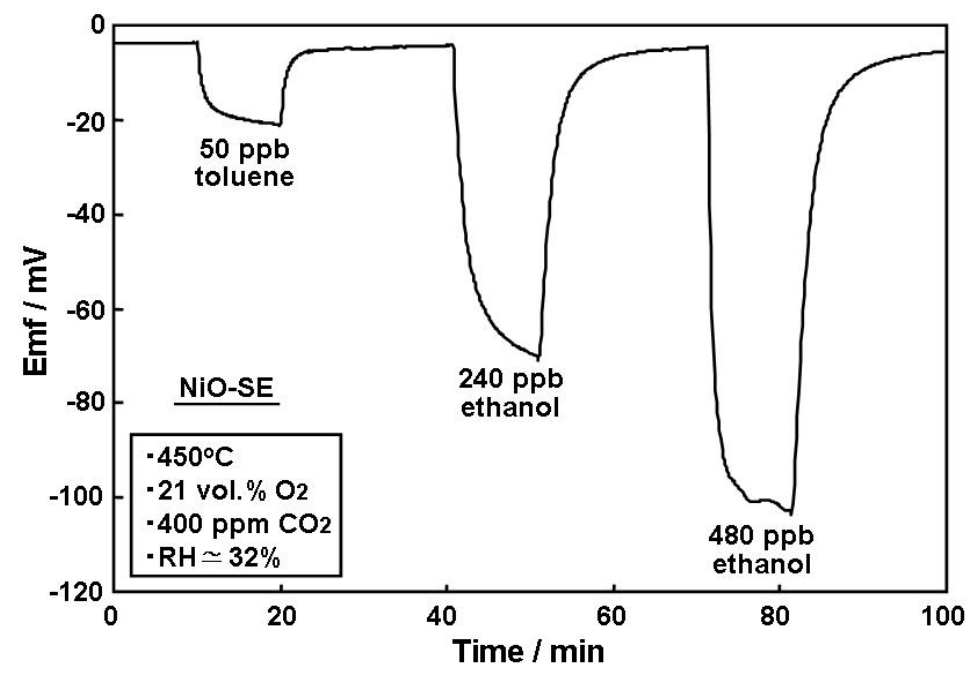

To decrease ethanol sensitivity and improve toluene selectivity, a gas-phase catalyst was applied upstream of the sensor to achieve selective ethanol oxidation. The application of catalysts for YSZ-based sensors has been reported for the selective detection of HCs [18], NOx [19] and $\mathrm{NH}_{3}$ [20], which dealt with high concentrations of gases at parts per million (ppm) levels exhausted from vehicles, where conditions are completely different from those found in indoor environments (several tens of ppb). Recently, we have reported that the lamination of a $\mathrm{ZnO}$ layer onto the $\mathrm{SnO}_{2}-\mathrm{SE}$ of a YSZ-based amperometric sensor can improve $\mathrm{C}_{3} \mathrm{H}_{6}$ selectivity to ppb levels in atmospheric environments [21].

To find a suitable catalyst for the selective oxidation of ethanol, the catalytic activity of four different oxides were evaluated by measuring the downstream concentrations of toluene and ethanol after passing through a catalytic cell loaded with one of the respective oxide powder. The downstream gas concentration was analyzed with a YSZ-based sensor utilizing $\mathrm{NiO}\left(+20 \mathrm{wt} \%\right.$ nano $\left.\mathrm{Al}_{2} \mathrm{O}_{3}\right)-\mathrm{SE}$, which was confirmed to be sufficiently sensitive for the detection of ppb toluene and ethanol concentrations.

Prior to evaluation, the calibration curves towards each sample gas were measured for the present sensor, as can be seen in Figure 3. The results given in Figure 3 indicated that the sensor showed almost linear trends of concentration dependence on sensitivity, indicating the approximate concentration determined by the sensor. The observed trend of the dependence was different from that of general mixed-potential type sensors [22-25] whose sensitivity typically varies linearly with the logarithm of gas concentration. This unusual linear behavior in the limited sensitivity region in Figure 3 was reported to be due to gas-diffusion limiting behavior in SE layer [26]. The slope of each calibration curve was $-0.53 \mathrm{mV} / \mathrm{ppb}$ for toluene and $-1.13 \mathrm{mV} / \mathrm{ppb}$ for ethanol. In Figure 3 , gas sensitivity $(\Delta \mathrm{emf})$ was defined as the difference in electromotive force (emf) measured in base gas and sample gas. 
Figure 3. Calibration curves of YSZ-based sensor utilizing $\mathrm{NiO}\left(+\mathrm{Al}_{2} \mathrm{O}_{3}\right)$-SE towards toluene and ethanol at an operational temperature of $450{ }^{\circ} \mathrm{C}$ under humid conditions $(\mathrm{RH} \simeq 32 \%)$.

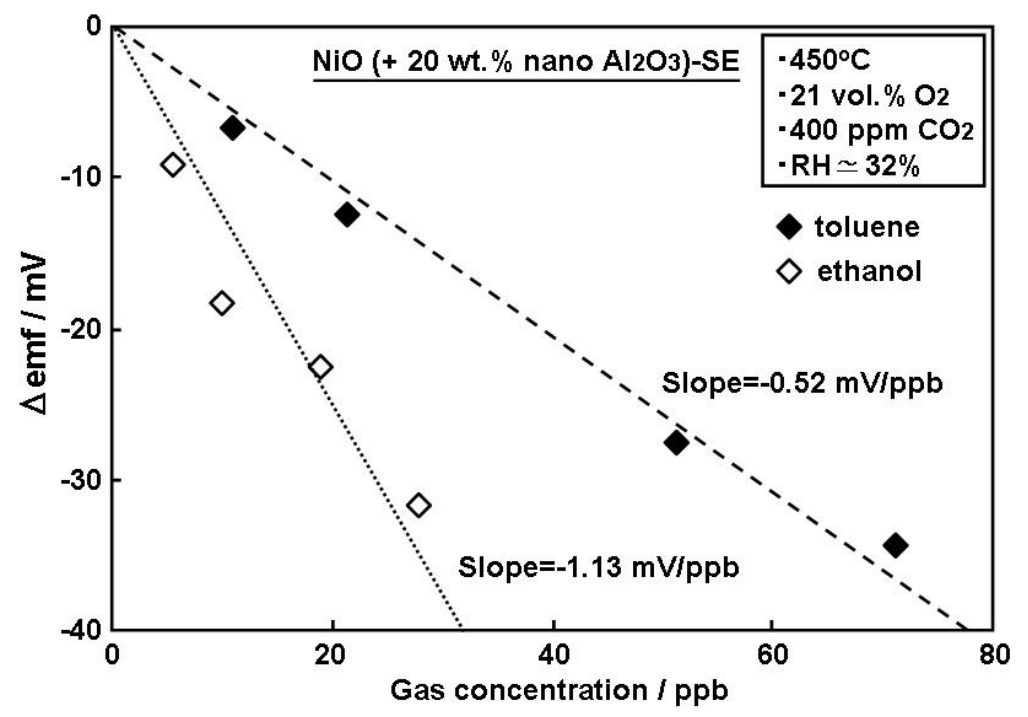

Figure 4. Catalytic activity comparison of different oxides for the oxidation of toluene and ethanol, evaluated with a YSZ-based sensor utilizing $\mathrm{NiO}\left(+\mathrm{Al}_{2} \mathrm{O}_{3}\right)-\mathrm{SE}$ at an operational temperature of $450{ }^{\circ} \mathrm{C}$ under humid conditions $(\mathrm{RH} \simeq 32 \%)$.

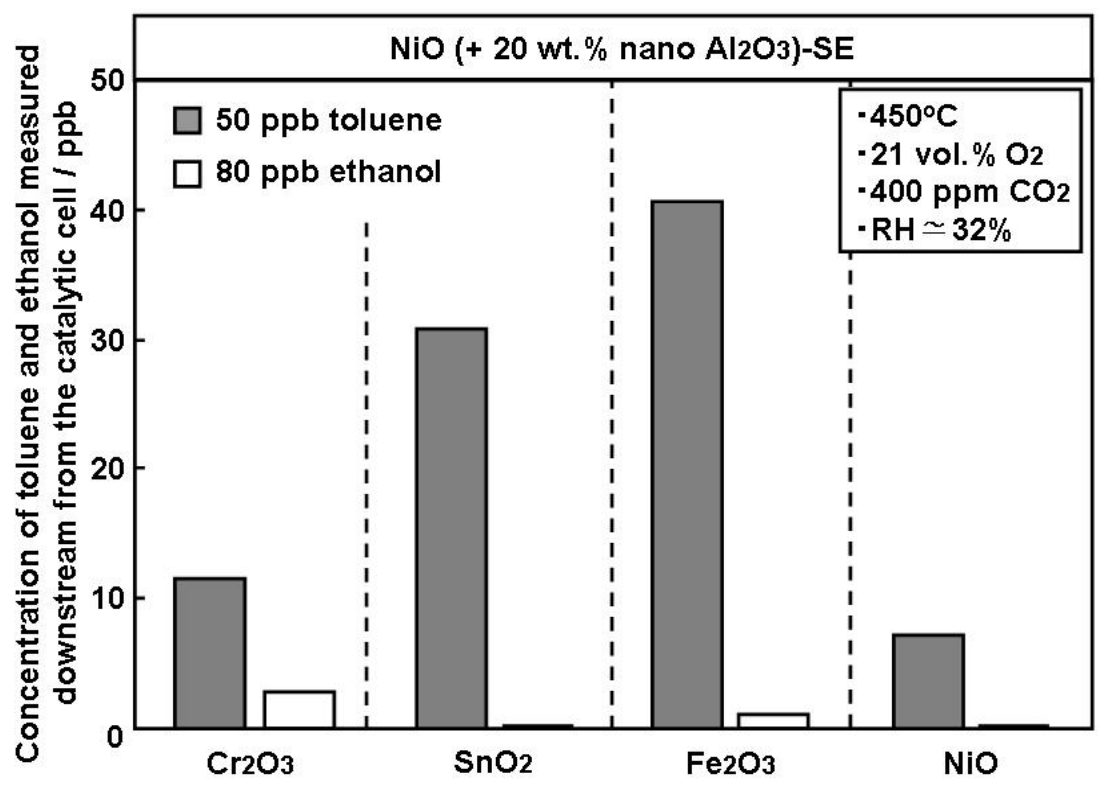

Figure 4 compares the catalytic activity of various oxide powders for toluene and ethanol oxidation. The evaluation was performed under a humid and carbonized atmosphere at $450{ }^{\circ} \mathrm{C}$, which is the same operational parameters as the YSZ-based sensor, considering the future potential for catalyst lamination onto the $\mathrm{SE}$ as a prospective research avenue. The downstream concentrations estimated by the YSZ-based sensor utilizing $\mathrm{NiO}\left(+\mathrm{Al}_{2} \mathrm{O}_{3}\right)$-SE revealed that all catalysts have a higher catalytic activity for ethanol oxidation rather than toluene, which is expected as ethanol is generally easily adsorbed and catalytically decomposed on oxide surfaces, even at temperatures below $300{ }^{\circ} \mathrm{C}$ [27-29]. However, $\mathrm{Cr}_{2} \mathrm{O}_{3}$ and $\mathrm{NiO}$ also decomposed approximately $80 \%$ of toluene, indicating that the 
application of these catalysts in a sensing system would most likely cause a drastic decrease in toluene sensitivity. This result supports data presented in our previous paper [15], regarding the observation that an increase in the thickness of NiO-SE decreases toluene sensitivity. Among the oxides tested, $\mathrm{SnO}_{2}$ was selected as a suitable catalyst for the selective toluene sensing-system owing to its ability to selectively oxidize ethanol, while maintaining $\mathrm{C}_{7} \mathrm{H}_{8}$ response. Similary, $\mathrm{Fe}_{2} \mathrm{O}_{3}$ was also found to be effective at oxidizing $\mathrm{C}_{2} \mathrm{H}_{5} \mathrm{OH}$, however as $\mathrm{Fe}_{2} \mathrm{O}_{3}$ incompletely oxidized $\mathrm{C}_{2} \mathrm{H}_{5} \mathrm{OH}$, its use was discontinued for further experimentation. The ability of $\mathrm{SnO}_{2}$ to almost completely oxidize $\mathrm{C}_{2} \mathrm{H}_{5} \mathrm{OH}$ is of critical importance as there is often high ethanol concentration in indoor atmosphere (1.48 ppm) [16].

A selective toluene sensing-system was constructed by placing a quartz cell loaded with $20 \mathrm{mg}$ of $\mathrm{SnO}_{2}$ powder, upstream of the YSZ-based sensor utilizing NiO-SE. Figure 5 shows the comparison of cross sensitivities towards toluene and interfering gases, including high concentration ethanol for the sensor using NiO-SE with and without a $\mathrm{SnO}_{2}$ catalytic cell, at an operational temperature of $450{ }^{\circ} \mathrm{C}$ under humid conditions. It can be clearly seen that the application of the catalytic cell caused a drastic decrease in ethanol sensitivity; from $-98 \mathrm{mV}$ to $-1.5 \mathrm{mV}$ for $480 \mathrm{ppb}$ ethanol by oxidizing ethanol in the $\mathrm{SnO}_{2}$ catalyst cell, although toluene sensitivity was also slightly affected. The sensitivities towards other interfering gases also decreased, which indicates that the $\mathrm{SnO}_{2}$ powder presumably partially catalyses $\mathrm{C}_{3} \mathrm{H}_{6}, \mathrm{H}_{2}, \mathrm{CO}$ and $\mathrm{NO}_{2}$, causing high toluene selectivity. The developed sensing system was confirmed to selectively detect very low concentrations of toluene at ppb levels, by catalyzing interfering gases. The investigation of this catalyst via the direct lamination of a $\mathrm{SnO}_{2}$ layer onto $\mathrm{NiO}-\mathrm{SE}$ for a compact sensor is currently under investigation.

Figure 5. Comparison of cross sensitivities towards different gases (a) YSZ-based sensor utilizing NiO-SE; (b) YSZ-based sensor utilizing NiO-SE with $\mathrm{SnO}_{2}$ oxidation cell at an operational temperature of $450{ }^{\circ} \mathrm{C}$ under humid conditions $(\mathrm{RH} \simeq 32 \%)$.

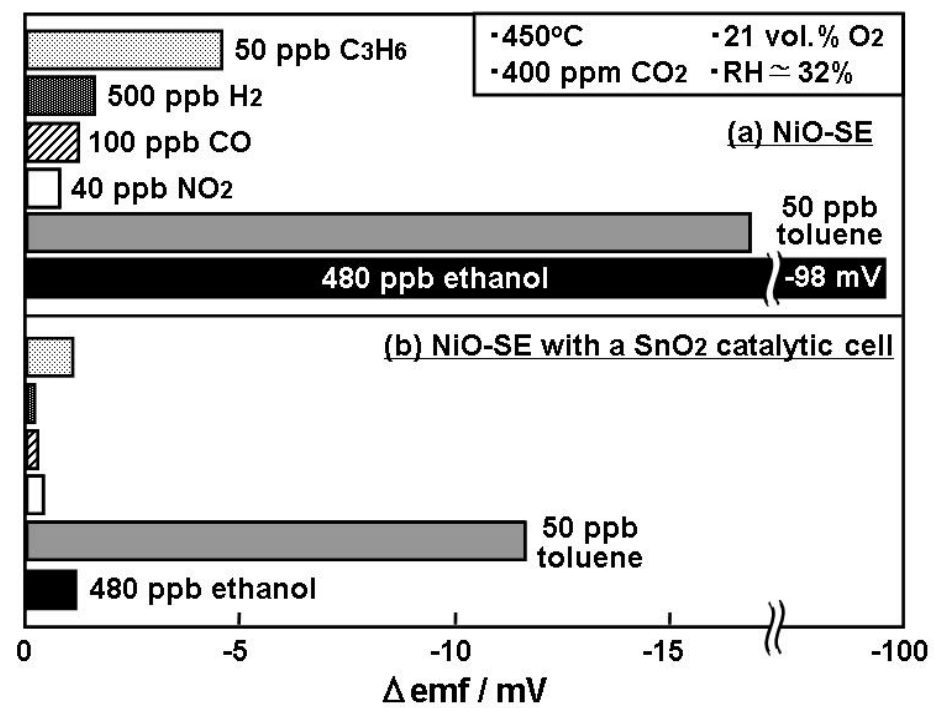

\section{Conclusions}

The application of a $\mathrm{SnO}_{2}$ catalytic cell upstream of a YSZ-based sensor utilizing NiO-SE resulted in a great improvement of toluene selectivity due to the oxidation of high concentration ethanol $(480 \mathrm{ppb})$ before it reaches to TPB. The detectable levels of toluene (50 ppb) in the developed sensing 
system was found to be less than the indoor guideline concentration (70 ppb), established by the Japanese government for the prevention of sick building syndrome. In addition, effects caused by other interfering gases such as $\mathrm{C}_{3} \mathrm{H}_{6}, \mathrm{H}_{2}, \mathrm{CO}$ and $\mathrm{NO}_{2}$ were negligible, demonstrating that the developed sensing system could be utilized as a selective toluene-monitoring device capable of detecting ppb levels in real indoor environments.

\section{Acknowledgments}

This work was partially supported by Kyushu University program, G-COE on "Novel Carbon Resource Sciences" and Grant-in-aid for Scientific Research (B) (22350095), as well as for JSPS Fellows (22-0353).

\section{References}

1. Mori, M.; Nishimura, H.; Itagaki, Y.; Sadaoka, Y. Potentiometric VOC detection in air using 8YSZ-based oxygen sensor modified with $\mathrm{SmFeO}_{3}$ catalytic layer. Sens. Actuators B 2009, 142, 141-146.

2. Luo, S.; Fu, G.; Chen, H.; Zhang, Y. Gas sensing properties and complex impedance analysis of $\mathrm{La}_{2} \mathrm{O}_{3}$-added $\mathrm{WO}_{3}$ nanoparticles to VOC gases. Mater. Chem. Phys. 2009, 109, 541-546.

3. Sasahara, T.; Kato, H.; Saito, A.; Nishimura, M.; Egashira, M. Development of a ppb-level sensor based on catalytic combustion for total volatile organic compounds in indoor air. Sens. Actuators $B$ 2007, 126, 536-543.

4. Matsuguchi, M.; Uno, T. Molecular imprinting strategy for solvent molecules and its application for QCM-based VOC vapor sensing. Sens. Actuators B 2006, 113, 94-99.

5. Stegmeier, S.; Fleischer, M.; Hauptmann, P. Influence of the morphology of platinum combined with $\beta-\mathrm{Ga}_{2} \mathrm{O}_{3}$ on the VOC response of work function type sensors. Sens. Actuators B 2010, 148, 439-449.

6. Consales, M.; Crescitelli, A.; Penza, M.; Aversa, P.; Veneri, P.D.; Giordano, M.; Cusano, A. SWCNT nano-composite optical sensors for VOC and gas trace detection. Sens. Actuators $B$ 2009, 138, 351-361.

7. Shafer, T.B.; Seinfeld, J.H. Comparative analysis of chemical reaction mechanisms for photochemical smog-II. Sensitivity of E.K.M.A. to chemical mechanism and input parameters. Atmos. Environ. 1986, 20, 487-499.

8. Apter, A.; Bracker, A.; Hodgson, M.; Sidman, J.; Leung, W.Y. Epidemiology of the sick building syndrome. J. Allergy Clin. Immun. 1994, 94, 277-288.

9. Lewis, C.W.; Zweidinger, R.B. Apportionment of residential indoor aerosol, VOC and aldehyde species to indoor and outdoor sources, and their source strengths. Atmos. Environ. 1992, 26, 2179-2184.

10. Schlink, U.; Thiem, A.; Kohajda, T.; Richter, M.; Strebel, K. Quantile regression of indoor air concentrations of volatile organic compounds (VOC). Sci. Total Environ. 2010, 408, 3840-3851.

11. Gros, V.; Bonsang, B.; Esteve, R.S. Atmospheric carbon monoxide 'in situ' monitoring by automatic gas chromatography. Chemosphere 1999, 1, 153-161. 
12. Jeltes, R.; Burghardt, E. Automatic gas chromatographic measurement of $\mathrm{C}_{1}-\mathrm{C}_{5}$ hydrocarbons in air. Atmos. Environ. 1972, 6, 793-805.

13. Mavroidis, I.; Chaloulakou, A. Long-term trends of primary and secondary $\mathrm{NO}_{2}$ production in the Athens area. Variation of the $\mathrm{NO}_{2} / \mathrm{NOx}$ ratio. Atmos. Environ. 2011, 45, 6872-6879.

14. Sato, T.; Plashnitsa, V.V.; Utiyama, M.; Miura, N. Potentiometric YSZ-based sensor using NiO sensing electrode aiming at detection of volatile organic compounds (VOCs) in air environment. Electrochem. Commun. 2010, 12, 524-526.

15. Sato, T.; Plashnitsa, V.V.; Utiyama, M.; Miura, N. YSZ-based sensor using NiO sensing electrode for detection of volatile organic compounds in ppb level. J. Electrochem. Soc. 2011, 158, J175-J178.

16. Gallego, E.; Roca, X.; Perales, J.F.; Guardino, X. Determining indoor air quality and identifying the origin of odour episodes in indoor environments. J. Environ. Sci. 2009, 21, 333.

17. Committee on Sick House Syndrome: Indoor Air Pollution. Progress Report No.1-Summary on the discussions from the 1st to 3rd meetings; Ministry of Health, Labour and Welfare: Tokyo, Japan, 2000; Volume 1, pp. 1-9. Available online: http://www.nihs.go.jp/mhlw/chemical/situnai/ kentoukai/rep-eng1.pdf (accessed on 22 February 2012).

18. Nakatou, M.; Miura, N. Detection of combustible hydrogen-containing gases by using impedancemetric zirconia-based water-vapor sensor. Solid State Ionics 2005, 176, 2511-2515.

19. Yang, J.C.; Dutta, P.K. Promoting selectivity and sensitivity for a high temperature YSZ-based electrochemical total NOx sensor by using a Pt-loaded zeolite Y filter. Sens. Actuators B 2007, 125, 30-39.

20. Schonauer, D.; Wiesner, K.; Fleischer, M.; Moos, R. Selective mixed potential ammonia exhaust gas sensor. Sens. Actuators B 2009, 140, 585-590.

21. Wama, R.; Plashnitsa, V.V.; Elumalai, P.; Utiyama, M.; Miura, N. Impedancemetric zirconiabased sensor attached with laminated-oxide sensing-electrode aiming at highly sensitive and selective detection of propene in atmospheric air. Solid State Ionics 2010, 181, 359-363.

22. Fischer, S.; Pohle, R.; Farber, B.; Proch, R.; Kaniuk, J.; Fleischer, M.; Moos, R. Method for detection of NOx in exhaust gases by pulsed discharge measurements using standard zirconia-based lambda sensors. Sens. Actuators B 2010, 147, 780-785.

23. Fujio, Y.; Plashnitsa, V.V.; Elumalai, P.; Miura, N. Stabilization of sensing performance for mixed-potential-type zirconia-based hydrocarbon sensor. Talanta 2011, 85, 575-583.

24. Plashnitsa, V.V.; Anggraini, S.A.; Miura, N. CO sensing characteristics of YSZ-based planar sensor using Rh-sensing electrode composed of tetrahedral sub-micron particles. Electrochem. Commun. 2011, 13, 444-446.

25. Park, J.; Yoon, B.Y.; Park, C.O.; Lee, W.J.; Lee, C.B. Sensing behavior and mechanism of mixed potential NOx sensors using $\mathrm{NiO}, \mathrm{NiO}(+\mathrm{YSZ})$ and $\mathrm{CuO}$ oxide electrodes. Sens. Actuators B 2009, $135,516-523$.

26. Garzon, F.H.; Mukundan, R.; Brosha, E.L. Solid-state mixed potential gas sensors: Theory, experiments and challenges. Solid State Ionics 2000, 136, 633-638.

27. Larsson, P.O.; Anderssony, A. Complete oxidation of CO, ethanol, and ethyl acetate over copper oxide supported on titania and ceria modified titania. J. Catal. 1998, 179, 72-89. 
28. Wang, W.; Zhang, H.B.; Lin, G.D.; Xiong, Z.T. Study of $\mathrm{Ag} / \mathrm{La} a_{0.6} \mathrm{Sr}_{0.4} \mathrm{MnO}_{3}$ catalysts for complete oxidation of methanol and ethanol at low concentrations. Appl. Catal. B 2000, 24, 219-232.

29. Morales, M.R.; Barbero, B.P.; Cadus, L.E. Total oxidation of ethanol and propane over $\mathrm{Mn}-\mathrm{Cu}$ mixed oxide catalysts. Appl. Catal. B 2006, 67, 229-236.

(C) 2012 by the authors; licensee MDPI, Basel, Switzerland. This article is an open access article distributed under the terms and conditions of the Creative Commons Attribution license (http://creativecommons.org/licenses/by/3.0/). 